\title{
Begomovírus infectando a cultura de pimentão no Estado de São Paulo**
}

Denise Nakada Nozaki ${ }^{*}$, Renate Krause-Sakate ${ }^{1} \&$ Marcelo Agenor Pavan $^{1}$

${ }^{1}$ Faculdade de Ciências Agronômicas, UNESP, Departamento de Produção Vegetal, Setor Defesa Fitossanitária, CP 237, CEP 18.603-970, Botucatu, SP. *Bolsista CAPES.

**Parte da Tese de Doutorado do primeiro autor. Trabalho financiado pela FAPESP

Autor para correspondência: Denise Nakada Nozaki (denozaki@ hotmail.com)

Data de chegada: 07/05/2007. Aceito para publicação em: 10/09/2010.

\section{RESUMO}

Nozaki, D.N.; Krause-Sakate, R. \& Pavan, M.A. Begomovírus infectando a cultura de pimentão no Estado de São Paulo. Summa Phytopathologica, v.36, n.3, p.244-247, 2010.

Vírus do gênero Begomovirus são transmitidos por mosca-branca Bemisia tabaci G., e constituem um dos problemas fitossanitários sérios em diversas culturas. Plantas de pimentão coletadas em oito regiões do Estado de São Paulo, foram submetidas a extração de DNA total e PCR com primers universais e degenerados para begomovírus, que amplificam parte da região codificadora para a proteína capsicial. Os dados indicam a presença de begomovírus em pimentão nas cinco regiões coletadas. Análise das seqüências do DNA viral e análise filogenética revelaram identidade com dois begomovírus nativo da América. Tomato severe rugose virus - ToSRV (AY029750) e com Tomato yellow vein streak virus (ToYVSV, AY829113), espécies descritas infectando tomateiro no Brasil. A presença de begomovírus em pimentão foi verificada nas regiões de Alvinlândia, Ubirajara, Botucatu, Elias-Fausto, Paulínia, Mogi Guaçu, Paranapanema e Pirajú.

Palavras-chave adicionais: Capsicum annuum, Tomato severe rugose virus, Tomato yellow vein streak vírus.

\begin{abstract}
Nozaki, D.N.; Krause-Sakate, R. \& Pavan, M.A. Begomovirus infecting pepper crops in São Paulo State. Summa Phytopathologica, v.36, n.2, p.244-247, 2010.

Virus to the genus Begomovirus transmitted by whiteflies Bemisia tabaci G., and considered one of the most important fitossanitary problems for several cultures. Pepper plants were collected in eight the regions of São Paulo State, the extraction of total DNA and PCR were submitted with universal and degenerate primers was used to amplify partial sequences of the begomovírus coat protein gene. The data indicated the presence of begomovírus in five collected regions.

DNA viral sequence analysis and phylogenetic analysis revealed identity with two native begomovírus of America. Tomato severe rugose virus - ToSRV (AY029750) and with Tomato yellow vein streak virus (ToYVSV, AY829113), described species infecting tomateiro in Brazil. The begomovírus presence in pepper plant was verified in the areas of Alvinlândia, Ubirajara, Botucatu, Elias-Fausto, Paulínia, Mogi Guaçu, Paranapanema and Pirajú.
\end{abstract}

Keywords: Capsicum annuum L, Tomato severe rugose virus, Tomato yellow vein streak virus

Os vírus pertencentes à família Geminiviridae são caracterizados pela morfologia de partículas icosaédricas geminadas e genoma composto por DNA de fita simples circular $(4,09)$. A família é dividida nos gêneros Mastrevirus, Curtovirus, Topocuvirus e Begomovirus, com base no número de componentes do genoma, tipo de inseto vetor, gama de hospedeiros e relacionamento filogenético (09). Os vírus do gênero Begomovirus, são transmitidos por moscas brancas (Bemisia tabaci Genn.) e infecta dicotiledôneas, de uma maneira geral, causando grande prejuízo em várias culturas em todo mundo. Possui o genoma bipartido ou monopartido (DNA-A ou DNA-B), sendo cada um dos componentes (DNA-A e DNA-B) responsável por etapas distintas do processo de infecção. O DNA-A é responsável pela replicação viral e formação da capa protéica enquanto que o DNA-B é responsável pela disseminação (célula-a-célula e longa distância) do vírus na planta (4).

Em pimentão o primeiro relato de begomovírus no Brasil foi feito por Lima et al. (5), que verificou um total de $43,8 \%$ de infecção nas amostras da cultivar S-59 e o híbrido Tango coletadas nos municípios de Curaçá (Bahia) e Petrolina (Pernambuco) no Submédio do Vale São Francisco, causando, em média, 20\% de perda na produção (6). Bezerra et al. (1) observaram em Petrolina de Goiás (estado de Goiás) sintomas de mosaico amarelo e distorção de folha em pimenta dedo-de-moça, tendo sido verificada a espécie ToSRV (AY029750). No estado de São Paulo foi verificada a mesma espécie ocorrendo em pimentão no ano de 2005 (6).

O objetivo deste trabalho foi determinar os possíveis locais de ocorrência de begomovirus na cultura de pimentão no estado de São Paulo e identificar as espécies predominantes nesta cultura.

Plantas de pimentão, com sintomas de amarelecimento e distorção foliar, foram coletadas para verificar a presença de begomovírus, no período compreendido entre novembro de 2004 a maio de 2006 em 16 propriedades produtoras nas oito regiões. Plantas de pimentão cultivado em casa-de-vegetação, foram usados como controle negativo. Em campo de produção de pimentão em cultivo aberto, foram coletadas 
119 amostras de plantas de pimentão 'Magali R', 'Ikeda Casca Dura', 'P36R' e 'Nathalie' distribuídos nos municípios de Elias Fausto, Botucatu, Paulínia e Mogi Guaçu. Sob estufa foram coletadas 43 amostras de híbridos de pimentão 'P36', 'Lilac' e 'Mandarin' nos municípios de Paranapanema e Piraju, e 66 amostras de pimenta Dínamo e híbridos de pimentão 'Atlantic' e 'Máximo' na região de Marília, municípios de Alvilândia e Ubirajara (Tabela 1).

O DNA total foi extraído individualmente de cada planta usando o método descrito por Dellaporta et al. (1983). A diagnose inicial foi realizada via "Polymerase Chain Reaction" (PCR) utilizando os oligonucleotídeos iniciadores "universais" PALIv1978/PAR1c496, desenvolvidos para detecção de Begomovirus (08). Eletroforese em gel de agarose (1\%) dos produtos obtidos após PCR indicou a presença de um único fragmento com cerca de 1100 pares de bases. O termociclador (Mastercycler Gradient - Eppendorf) foi programado para uma desnaturação inicial a $95^{\circ} \mathrm{C}$ por 2 minutos, seguido de 25 ciclos a $94^{\circ} \mathrm{C}$ por 1 minuto, $57^{\circ} \mathrm{C}$ por 2 minutos e $72^{\circ} \mathrm{C}$ por 2 minutos e uma extensão final a $72^{\circ} \mathrm{C}$ por 10 minutos. O DNA das amostras positivas para begomovírus foram amplificados novamente por PCR para obtenção de um fragmento correspondente à região do gene que codifica a proteína capsidial com o par de oligonucleotídeos PrV324 e PrC889 (10).

O produto de PCR foi diretamente seqüenciado. As seqüências de cada isolado foram comparadas entre si e com outras seqüências do GenBank (www.ncbi.nlm.nih.gov/blast/) como: Tomato rugose mosaic virus (ToRMV, número de acesso AF291705), Tomato chlorotic mottle virus (ToCMoV, AF490004), Sida mottle virus (SiMoV, AY090555), Tomato golden vein virus (ToGVV, AY751742), Bean golden mosaic virus (BGMV, M88686-7), Tomato severe rugose virus (ToSRV, AY029750 e DQ207749) e Tomato yellow vein streak virus (ToYVSV, DQ3559770) e alinhadas e construída a árvore filogenética com o programa MEGA v.3.1, utilizando o método de "neighbor-joining", com valor de "bootstrap" 2000.

Nos municípios de Paulínia, Botucatu e na primeira coleta em Elias Fausto nenhuma das amostras coletadas mostraram-se infectadas por begomovírus. De fato, não foram observadas moscas brancas nos locais de coleta, e provavelmente a incidência estava muito baixa, ou mesmo nula. No município de Paranapanema sete das 13 amostras foram positivas correspondendo a 53,8\% das amostras coletadas. Em Piraju, das 30 amostras coletadas, nove foram positivas (30\%). Em Alvinlândia, região de Marília, das 40 plantas coletadas apenas uma mostrou-se infectada $(2,5 \%)$ e em Ubirajara, região de Bauru, das 26 amostras, uma era positiva (3,8\%). Em Mogi Guaçu foram coletadas 38 plantas de pimentão sendo que seis mostraram-se positivas por PCR $(15,8 \%)$ e, em Elias Fausto, de 23 plantas coletadas apenas seis mostraram-se infectadas ou positivas por PCR $(26,1 \%)$. Em todas as regiões onde foram encontradas amostras positivas, encontravam-se populações de mosca-branca. Nas regiões de Paranapanema, Piraju, e Marília a área de cultivo de pimentão havia sido anteriormente utilizada com tomateiro.

As amostras positivas para begomovírus foram em seguida submetidas a re-amplificação com os oligonucleotídeos PrV324/PrC889 para estudo da diversidade genética e identificação das prováveis espécies presentes. Este par de oligonucleotídeos amplificou um fragmento de aproximadamente 576 nucleotídeos correspondente ao gene que codifica a proteína capsidial (CP), localizado no DNA-A dos begomovírus, correspondendo a região do nucleotídeo 377 ao 826 da capa protéica de Tomato severe rugose virus (DQ207749) de Petrolina de Goiás, Brasil.

Segundo Brown et al. (2001), o sequenciamento da porção 5' da região codificadora para a proteína capsidial permite uma classificação provisória da espécie de begomovírus infectando a amostra, porém com a ressalta já alertada por Padidam et al. (1999) da ocorrência de frequentes recombinações entre isolados de begomovírus e o problema de se utilizar uma pequena região genômica para classificar o isolado em espécie. Deste modo, os oligonucleotídeos PrV324 e PrC889 amplificam a porção 5' do genoma dos begomovírus e foram utilizados para classificação provisória dos isolados coletados.

Foram sequenciados 23 isolados, sendo oito da região de Piraju, cinco de Paranapanema, um de Alvinlândia, um de Ubirajara, cinco de

Tabela 1. Localização onde plantas de pimentão foram coletadas para análise no período compreendido entre 2004 a 2006.

\begin{tabular}{|c|c|c|c|c|c|c|}
\hline \multirow{2}{*}{ Localidade } & \multirow{2}{*}{ Cultivar } & \multirow{2}{*}{ Sistema de cultivo $^{a}$} & \multirow{2}{*}{$\begin{array}{l}\text { População de } \\
\text { Mosca-branca }\end{array}$} & \multicolumn{2}{|c|}{$\mathrm{N}^{\circ}$ de amostras } & \multirow{2}{*}{$\begin{array}{c}\% \text { de } \\
\text { infecções }\end{array}$} \\
\hline & & & & coletadas & Infectadas & \\
\hline Elias Fausto & Magali R & $\mathrm{Cca}$ & Ausente & 29 & 0 & 0 \\
\hline Botucatu & Ikeda Casca Dura & $\mathrm{Cca} / \mathrm{Ce}$ & baixa & 5 & 0 & 0 \\
\hline Paranapanema & P36R & $\mathrm{Ce}$ & alta & 13 & 7 & 53,8 \\
\hline Piraju & Lilac & $\mathrm{Ce}$ & Alta & 30 & 9 & 30 \\
\hline \multirow[t]{2}{*}{ Alvinlândia } & Atlantic & $\mathrm{Ce}$ & Baixa & 40 & 1 & 2,5 \\
\hline & Pimenta Dínamo & $\mathrm{Ce}$ & Baixa & & & \\
\hline \multirow[t]{2}{*}{ Ubirajara } & Máximo & $\mathrm{Ce}$ & baixa & 26 & 1 & 3,8 \\
\hline & Pimenta Dínamo & $\mathrm{Ce}$ & Baixa & & & \\
\hline \multirow[t]{2}{*}{ Mogi Guaçu } & P36R & Cca & Baixa & 38 & 6 & 15,8 \\
\hline & Nathalie & $\mathrm{Cca}$ & Alta & & & \\
\hline Elias Fausto & Magali R & Cca & Alta & 23 & 6 & 26,1 \\
\hline
\end{tabular}

${ }^{a} \mathrm{Cca}=$ cultivo em campo aberto; $\mathrm{Ce}=$ cultivo em estufa e $\mathrm{Ni}=$ não identificada 


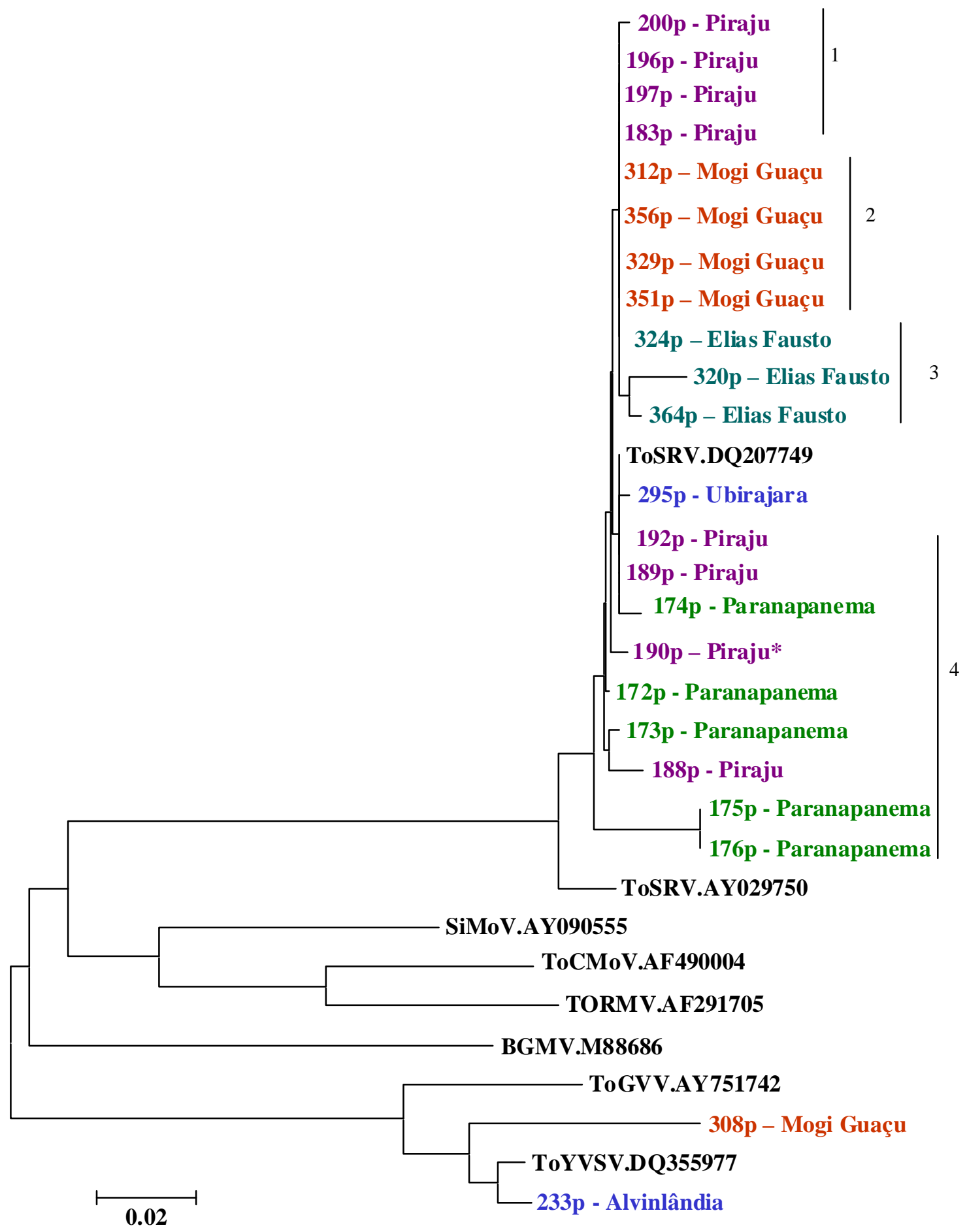

Figura 1. Análise filogenética de begomovirus infectando pimentão no Estado de São Paulo e outros begomovírus do GenBank, baseado no alinhamento de nucleotídeos referente à parte da região codificadora para a capa protéica obtida com o oligonucleotídeo PrV324. Valor de Bootstrap 2000, Programa Mega Versão 3.1.

Mogi Guaçu e três de Elias Fausto. Comparação das seqüências obtidas com as demais seqüências disponíveis no GenBank, demonstrou duas espécies distintas de begomovírus ocorrendo em pimentão. A análise permitiu a separação de dois ramos filogenéticos (Figura 1). O primeiro ramo compreendendo isolados de Tomato severe rugose virus (ToSRVAY029750 e DQ207749), foi constituído por todos os isolados oriundos das regiões de Paranapanema, Piraju, Ubirajara, Elias Fausto e três de Mogi Guaçu. No segundo ramo, foram agrupados o isolado de Alvinlândia (233p), e um isolado de Mogi Guaçu (308), a espécie tentativa Tomato yellow vein streak virus (ToYVSV) e o Tomato golden vein virus (ToGVV). A maioria dos isolados apresentaram identidade variando de 98 a 100\% com o ToSRV, seqüenciado de pimenta na região de Petrolina de Goias, indicando predominância desta espécie nos campos analisados no Estado de São Paulo. O isolado 233p de 
Alvinlândia e o 308p de Mogi Guaçu apresentaram identidade de 98 e 95\% com ToYVSV respectivamente.

A análise das sequiências de begomovirus obtidas neste trabalho com demais disponíveis no GenBank identificaram a ocorrência das espécies Tomato severe rugose virus (ToSRV) nas regiões de Paranapanema, Piraju e Marília e do Tomato golden vein virus (ToGVV, AY751742) ou Tomato yellow vein streak virus (ToYVSV, AY829113) em Alvinlândia e Mogi Guaçu.

Os resultados aqui obtidos revelaram que as espécies ToSRV e ToYVSV/ToGVV que haviam sido relatadas até então no Brasil em tomateiro, estão infectando também o pimentão e utilizando esta planta como possível hospedeira alternativa.

\section{REFERÊNCIAS BIBLIOGRÁFICAS}

1. Bezerra-Agasie, I.C.; Ferreira, G.B.; Ávila, A.C.; Inoue-Nagata, A.K. First report of Tomato severe rugose virus in chili pepper in Brazil. Plant Disease, v.90, p.114, 2006.

2. Brown, J. K.; Idris, A. M.; Torres-Jerez, I.; Banks, G. K.; Wyatt, S. D. The core region of the coat protein gene is highly useful for establishing the provisional identification and classification of begomoviruses. Archives of Virology, Springer Wien, v.146, n. 8, p.1581-1598, 2001.

3. Dellaporta, S.L.; Woods, J.; Hicks, J.B. A plant minipreparations, version II. Plant Molecular Biolology Reporter, v.1, p.19-21, 1983.
4. Hanley-Bowdoin, L.; Settlage, S.B.; Orozco, B.M.; Nagar, S.; Robertson, D. Geminiviruses: Models for plant DNA replication, transcription, and cell cycle regulation.Critical Reviews in Plant Sciences, v. 18, p. 71-106, 1999.

5. Lima, M.F.; Bezerra, I.C.; Ribeiro, S.G. De Ávila, A.C. Distribuição de geminivírus nas culturas do tomate e pimentão em doze municípios do Submédio do Vale de São Francisco. Fitopatologia Brasileira, v.26, p. 81-85, 2001.

6. Nozaki, D.N.; Krause-Sakate, R.; Hasegawa, J.M.; Cezar, M.A.; Dziuba, P.H.; Pavan, M.A. First report of Tomato severe rugose virus infecting pepper plants in Brazil. Fitopatologia Brasileira, v. 31, n3, p.5040, 2006.

7. Padidam, M.; Sawyer, S. \& Fauquet, C. M. Possible emergence of new geminivirus by frequent recombination. Virology, v.265, p.218-225, 1999.

8. Rojas, M.R.; Gilbertson, R.L.; Russell, D.R.; Maxwell, D.P. Use of degenerate oligonucleotídeos in the polymerase chain reaction to detect whitefly-transmitted geminiviruses. Plant Disease, v. 77, p. 340-347, 1993.

9. Stanley, J.; Bisaro, D.M.; Briddon, R.W.; Brown, J.K.; Fauquet, C.M.; Harrison, B.D.; Rybicki, E.P.; Stenger, D.C. Family Geminiviridae. IN: Fauquet, C.M.; Mayo, M.A.; Maniloff, J.; Desselberger, U.; Ball, L.A. (eds). Virus Taxonomy. Eighth Report of the International Committee on Taxonomy of Viruses, San Diego, CA, USALondon, Elsevier/Academic Press; p.301-326, 2005.

10. Wyatt, S.D. \& Brown, J.K. Detection of subgroup III geminivirus isolates in leaf extracts by degenerate primers and polymerase chain reaction. Phytopathology, v.86, p.1288-1293, 1996. 